\title{
Design of Classroom Furniture for Use at Tertiary Institutions
}

\author{
Abdalla Esmaeel $^{1 *} \quad$ Diana Starovoytova $^{2} \quad$ Obadiah Maube $^{2} \quad$ Rabie Asad $^{1}$ \\ 1. Faculty of Industries Engineering and Technology, University of Gezira P. O. Box 20, Wadmdani, Sudan \\ 2. School of Engineering, Moi University P. O. Box 3900, Eldoret, Kenya
}

\begin{abstract}
The design of classroom desktop-chairs (one size fits all) in many institutions is usually done with no consideration of ergonomics. Therefore, there is a mismatch between classroom desktop-chairs dimensions and students' anthropometric characteristics. This may cause musculoskeletal disorders and affect learning effectiveness due to sitting for a long time in an awkward position. Ergonomically designed furniture is known to reduce musculoskeletal disorders and improve the attentiveness of students in the classroom environment. This research, therefore, aimed to use the concept of ergonomics to design classroom desktop-chair for students in Uasin-Gishu County. Anthropometric data was collected from a total of three hundred and eighty-two (382) students of both genders. The selected tertiary institutions for the survey were Moi University (MU), University of Eldoret (UoE), Rift Valley Technical Training Institute (RVTTI) and The Eldoret National Polytechnic (TENP). Fourteen (14) anthropometric measurements were taken from students with the help of anthropometric tools. The research applied fundamental engineering principles of product design and was carried out in compliance with ISO 72501: (Basic human body measurements for technological design part 1: Body measurement definitions and landmarks). The data obtained was analysed using Minitab 17.0 statistical package, to get the mean, standard deviation, minimum, maximum, $5^{\text {th }}, 50^{\text {th }}$ and $95^{\text {th }}$ percentiles. SolidWorks 2019 , was used to design a desktopchair. The analysed anthropometric data set was used to design, a suitable classroom desktop-chair. One type of ergonomically suitable classroom desktop-chair design was proposed to improve the match between classroom desktop-chairs dimensions and students' anthropometric characteristics. The analysed anthropometric data set can be used for the design of classroom desktop-chairs for students not only in the selected tertiary institutions but all over Kenya.
\end{abstract}

Keywords: Musculoskeletal disorders, Awkward posture, Classroom environment.

DOI: $10.7176 / \mathrm{ISDE} / 11-5-05$

Publication date:September $30^{\text {th }} 2020$

\section{Introduction}

In simple meaning, Anthropometry maybe defined as the study which deal with body dimensions i.e. body size, shape, strength and working capacity for design purposes (Taifa \& Desai, 2017). Anthropometric data is used in ergonomics to fit the workplace to the man, rather than fit the man to the workplace (Igbokwe, et al., 2019). Ergonomics is a science focused on the study of human fit, decreased fatigue, risk, hazed and discomfort through product design (Scott et al., 2006). The basic philosophy of ergonomics is to make any design of furniture which lead to comfortability, adaptability, suitability, physical health, safety, well-being, convenient and bring motive towards studies (Tunay \& Melemez, 2008). Anthropometric measurements vary from country to country at least with some small variations. Due to such variation, there is necessity of having a good database of anthropometric measurements in state wise if possible, thus as such data can be used for present time and future time in designing school furniture (Taifa \& Desai, 2017). Anthropometry has three major principles. These principles are mainly being followed in designing various products depending on the type of the product. The first principle is "design for extreme individual" which can be either design for the maximum population as commonly the $95^{\text {th }}$ percentile male or design for the minimum population value as commonly referred as $5^{\text {th }}$ percentile female. The second principle is "designing for an adjustable range" which put consideration of both $5^{\text {th }}$ female and $95^{\text {th }}$ male in order to accommodate $90 \%$ of the population. Adjustability principle has been much proposed by many researchers as the main ergonomics principles to be followed in designing furniture. The last principle is "designing for the average" which is mostly being used whenever the use of adjustability is impractical (Taifa \& Desai, 2017). The design of classroom desktop-chairs (one size fits all) in many institutions is usually done with no consideration of ergonomics. Therefore, there is a mismatch between classroom desktop-chairs dimensions and students' anthropometric characteristics. This may cause musculoskeletal disorders and affect learning effectiveness due to sitting for a long time in an awkward position. Ergonomically designed furniture is known to reduce musculoskeletal disorders and improve the attentiveness of students in the classroom environment. The main goals of this study, therefore, were (a) To contact anthropometric measurements for students from four selected tertiary institutions and (b) To design a desktop-chair using the collected anthropometric measurements.

\section{Literature review}

In the institutions, the classroom chair become the work environment for the students and effort has to be made to 
ensure that it is comfortable, suitable and can allow efficient learning. Therefore, the institution furniture such as chairs and desks are some of the most important facilities in the institutions, meanwhile students spend most of their time using them. On the other hand, studies have confirmed that students spend a greater part of their time in school in the seated posture (Ismaila, et al., 2013). Sitting position for a long period of time and static posture in a forward bending manner has been found to be the major cause of low back pain (Sepehri, Habibi, \& Shakerian, 2013). Leilanie Del Prado-Lu, (2004), observed that 60 percent of students complained of pains in the back, neck, or shoulder for which they blamed the furniture. Various studies have shown that the ill-fitted design of classroom furniture have contributed to the high incidence of musculoskeletal disorders (MSDs) among school children (Musa \& Ismaila, 2014). Improper design of chairs is one of the reasons of in appropriate sitting positions, which can lead to bad posture, fatigue, severe psychological stress and effects on students' performance (Ansari, et al., 2018). One more study demonstrated that wrongly designed school chairs and tables induce poor postures, leading to operational uneasiness and some musculoskeletal among students (Macedo et al., 2015). Besides, anthropometric sizes of students are an important factor that should be considered in designing school furniture. Most classroom activities involve sitting for long period of time. Due to prolonged sitting on inappropriate classroom furniture, students feel back pain and other musculoskeletal disorders (Biswas, et al., 2014). Moreover, variation between anthropometry and the actual measurement is definitely pose problems to the feet, ankles and thighs of the students. This study, therefore, seeks to use anthropometric for design of classroom desktop-chairs for students to improve physical responses and their performance.

\section{Research methodology}

\subsection{Sample Determinations and Measurements Procedure}

Four higher institutions in Uasin-Gishu County, Kenya, namely: (i) Moi University (MU), (ii) University of Eldoret (UoE), (iii) Rift Valley Technical Training Institute (RVTTI) and (iv) The Eldoret National Polytechnic (TENP) were selected to participate in the study. These institutions were chosen because they were quite interested in the study especially since it is basically on students' comfortability in their classroom environments. Three hundred and eighty-two (382) students (191 males and 191 females) were selected (at random) from four selected tertiary institutions, the body size of each student was assessed using standard anthropometric measurement techniques (Esmaeel \& Order, 2017). The consents of the students were obtained before the commencement of the measurements. In this study, stature (body height) dimensions for each student were taken while they are standing as well as the body mass. All other dimensions measured while they are sitting erect on adjustable desk with knees bent at $90^{\circ}$. All anthropometric measures were taken with the subjects wearing light clothing (shorts and t-shirts) in a relaxed and erect posture, without shoes and concerning the local culture (a female assistant was hired for measuring the females). Throughout the completion of all dimensions taken per subject, the time consumption was about 15 to 20 minutes. Furthermore, measurements were taken every working day for 20 days in February in year 2020, the students' measurements were done in Hostels for each of the four selected tertiary institutions and all measurements was measured in centimeter $(\mathrm{cm})$ expect the body mass by $(\mathrm{kg})$.

\subsection{Body Dimensions}

Designing of the standard desktop-chairs needs direct involvement of anthropometric measurements. Various researchers Igbokwe et al., (2019), suggested body dimensions which are essential in designing furniture, specifically for students. Figure 1 shows all twelve (12) body dimensions which were selected for this research with additional of weight and Forearm fingertip length as the fourteenth $\left(14^{\text {th }}\right)$ body measurement, this fourteenth anthropometric data are measured, because they are directly related in designing a classroom furniture as shown in table 1 . Two dimensions were collected while a participant in the standing position, the remaining twelfth $\left(12^{\text {th }}\right)$ dimensions were taken while the participant remained seated. All anthropometric data collected were based on ISO 7250-1:2017 (Basic human body measurements for technological design part 1: Body measurement definitions and landmarks) (Esmaeel \& Order, 2017). However, actual desktop-chair dimensions are determined by measurements of the human body (anthropometric measurements). However, actual chair dimensions are determined by measurements of the human body (anthropometric measurements). The two most relevant anthropometric measurement for chair design is the popliteal height and buttock popliteal length. The popliteal height is the distance from the underside of the foot to the underside of the thigh at the knees. It is sometimes called the "stool height". The term "sitting height" is reserved for the height to the top of the head when seated. The popliteal height, after adjusting for heels, clothing and other issues, is used to determine the height of the chair seat. The buttock popliteal length is the horizontal distance from the back most part of the buttocks to the back of the lower leg. This anthropometric measurement is used to determine the seat depth (Igbokwe et al., 2019). 


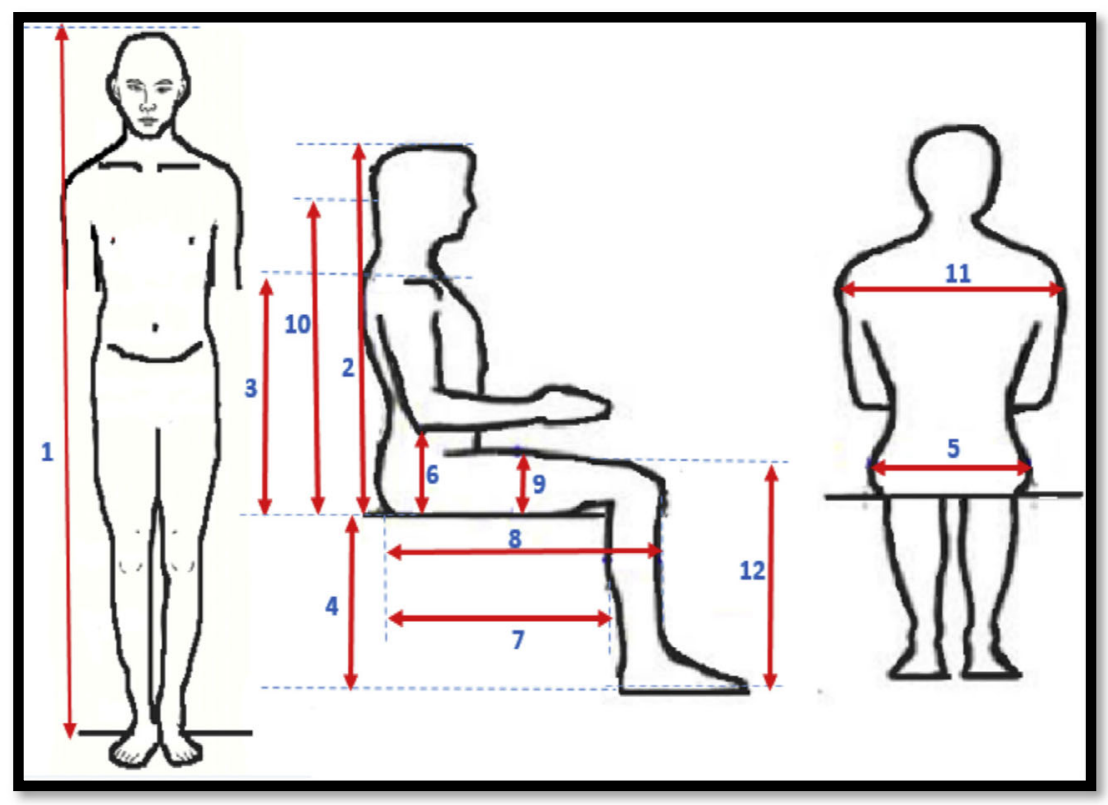

Keys: (1) stature (body height), (2) sitting height, (3) shoulder height, sitting, (4) lower leg length (popliteal height), (5) hip breadth, sitting, (6) elbow height, sitting, (7) buttock popliteal length (seat depth), (8) buttock knee length, (9) thigh clearance, (10) Eye height, sitting, (11) shoulder breadth and (12) knee height.

Figure 1. Anthropometric data required in classroom furniture design

Table 1. Selection of body measurements for classroom furniture design

\begin{tabular}{|c|c|c|}
\hline $\begin{array}{l}\text { S/NO. ACCORDING TO } \\
\text { ISO 7250-1:2017 }\end{array}$ & $\begin{array}{l}\text { BASIC STUDENTS } \\
\text { BODY DIMENSIONS }\end{array}$ & DESCRIPTION ACCORDING TO ISO 7250-1:2017 \\
\hline 6.1 .2 & Stature (body height) & $\begin{array}{l}\text { The vertical distance from the floor to the highest point of } \\
\text { the head (vertex). }\end{array}$ \\
\hline 6.2 .1 & Sitting height (erect) & $\begin{array}{l}\text { The vertical distance from a horizontal sitting surface to } \\
\text { the highest point of the head (vertex). }\end{array}$ \\
\hline 6.2 .4 & Shoulder height, sitting & $\begin{array}{l}\text { The vertical distance from a horizontal sitting surface to } \\
\text { the acromion. }\end{array}$ \\
\hline 6.2.11 & Popliteal height, sitting & $\begin{array}{l}\text { The vertical distance from the foot-rest surface to the } \\
\text { lower surface of the thigh immediately behind the knee, } \\
\text { bent at right angles. }\end{array}$ \\
\hline 6.2.10 & Hip breadth, sitting & $\begin{array}{l}\text { The breadth of the body measured across the widest } \\
\text { portion of the hips. }\end{array}$ \\
\hline 6.2 .5 & Elbow height, sitting & $\begin{array}{l}\text { The Vertical distance from a horizontal sitting surface to } \\
\text { the lowest bony point of the elbow bent at a right angle } \\
\text { with the forearm horizontal. }\end{array}$ \\
\hline 6.4.7 & $\begin{array}{l}\text { Buttock popliteal } \\
\text { length (seat depth) }\end{array}$ & $\begin{array}{l}\text { The horizontal distance from the hollow of the knee to the } \\
\text { rearmost point of the buttock. }\end{array}$ \\
\hline 6.4 .8 & Buttock knee length & $\begin{array}{l}\text { The horizontal distance from the foremost point of the } \\
\text { knee-cap to the rearmost point of the buttock. }\end{array}$ \\
\hline 6.2.12 & Thigh clearance & $\begin{array}{l}\text { The vertical distance from the sitting surface to the } \\
\text { highest point on the thigh. }\end{array}$ \\
\hline 6.2.2 & Eye height, sitting & $\begin{array}{l}\text { The vertical distance from a horizontal sitting surface to } \\
\text { the outer corner of the eye (ectocanthus). }\end{array}$ \\
\hline 6.2.8 & $\begin{array}{l}\text { Shoulder (bideltoid) } \\
\text { breadth }\end{array}$ & $\begin{array}{l}\text { The horizontal distance across the maximum lateral } \\
\text { protrusions of the right and left deltoid muscles. }\end{array}$ \\
\hline 6.2.13 & Knee height, sitting & $\begin{array}{l}\text { The vertical distance from the floor to the highest point of } \\
\text { the superior border of the patella (suprapatella, sitting). }\end{array}$ \\
\hline 6.1 .1 & Body mass (weight) & The total mass (weight) of the body. \\
\hline 6.4 .6 & $\begin{array}{l}\text { Forearm } \\
\text { length }\end{array}$ & $\begin{array}{l}\text { The horizontal distance from olecranon (back of the } \\
\text { elbow) to the tip of the middle finger, with the elbow bent } \\
\text { at right angles. }\end{array}$ \\
\hline
\end{tabular}




\subsection{Measuring Instruments and Materials}

A cording to Esmaeel \& Order, (2017), the standard measuring instruments recommended are:

Height was used to measure, stature (body height), Weighing scale was used to measure the body mass (weight), Anthropometer was used to measure, sitting height, elbow height sitting, shoulder height sitting, knee height, popliteal height sitting, eye height sitting, buttock popliteal length (seat death) and buttock knee length, Large sliding caliper (Range 0-600 mm with error $0.1 \mathrm{~mm}$ ) was used to measure, shoulder (bideltoid) breadth, hip breadth sitting, thigh clearance and forearm fingertip length.

\subsection{Data Analysis}

The data recorded were analysed statistically with the help of SPSS 16.0, Minitab 17.0 and Microsoft Excel (2016) programs. The anthropometric data was analysed using mean, standard deviation (St. Dev), minimum (min), maximum ( $\max ), 5^{\text {th }}$ percentile, $50^{\text {th }}$ percentile and $95^{\text {th }}$ percentile. SolidWorks 2019 (professional edition), as engineering software was used for modeling classroom desktop-chair. Results of the analysis are shown in Table 2 and Table 3. Only specific parts of the analysed data were used in the design of the classroom desktop-chair. It is wealth observing that not all the anthropometric measures are considered in the design of a model classroom desktop-chair.

\section{Results and Discussion}

\subsection{Anthropometric Dimension of Students}

The results obtained from the four selected tertiary institutions were analysed using SPSS 16.0 analysis, Microsoft Excel (2016) and Minitab 17.0 statistical package. The following results as shown in table 2 gives a summary of the anthropometric measures based on the mean, standard deviation $\left(S t\right.$. Dev), $5^{\text {th }}$ percentile, $50^{\text {th }}$ percentile and $95^{\text {th }}$ percentile of the collated anthropometric data, which can be used in designing a desktop-chair for use in the four selected tertiary institutions.

Table 2. Summary of anthropometric dimension among students of the selected institutions $(\mathrm{n}=832)$.

\begin{tabular}{|l|l|l|l|l|l|}
\hline Variable & Mean & St. Dev & $\begin{array}{c}5^{\text {th }} \\
\text { Percentile }\end{array}$ & $\begin{array}{c}5^{\text {th }} \\
\text { percentile }\end{array}$ & $\begin{array}{c}9^{\text {th }} \\
\text { Percentile }\end{array}$ \\
\hline Age (Yrs.) & 20.51 & 1.67 & 18.00 & 20.00 & 23.00 \\
\hline Stature & 168.38 & 7.86 & 155.50 & 168.00 & 182.00 \\
\hline Sitting height & 81.01 & 4.01 & 75.00 & 81.80 & 88.00 \\
\hline Shoulder height & 54.41 & 2.76 & 50.96 & 54.50 & 57.80 \\
\hline Popliteal height & 44.73 & 2.78 & 40.50 & 44.50 & 49.60 \\
\hline Hip breadth & 33.46 & 3.49 & 29.57 & 32.86 & 39.36 \\
\hline Elbow height & 23.76 & 2.84 & 19.11 & 23.65 & 28.17 \\
\hline Buttock popliteal length & 42.54 & 2.73 & 38.10 & 42.65 & 46.90 \\
\hline Buttock knee length & 51.85 & 3.05 & 47.20 & 51.90 & 56.70 \\
\hline Thigh clearance & 14.54 & 1.70 & 11.96 & 14.43 & 17.39 \\
\hline Eye height & 67.43 & 3.46 & 62.88 & 68.00 & 72.50 \\
\hline Shoulder breadth & 41.78 & 3.43 & 37.02 & 41.47 & 46.59 \\
\hline Knee height & 51.96 & 3.29 & 46.80 & 52.10 & 57.30 \\
\hline Body mass & 60.54 & 9.09 & 48.00 & 59.50 & 75.50 \\
\hline Forearm fingertip length & 47.62 & 2.70 & 43.46 & 47.44 & 51.88 \\
\hline
\end{tabular}

Literature suggests, the seat height, seat width, seat depth and backrest height are the important dimensions for the design of chair while desktop height from the seat, desktop width and desktop length are the dimensions that are essential for the design of the desktop. The design of the desktop-chair for use by students in the higher educations was based on the following criteria:

- Seat height: The popliteal height should be considered in the design of the seat height. Ismaila et al., (2013b), recommended $5^{\text {th }}$ percentile of popliteal height and allowance $0.45 \mathrm{~cm}$ for shoe heel. The $5^{\text {th }}$ percentile of the popliteal height is $40.50 \mathrm{~cm}$ and if this is added to shoe heel allowance of $0.45 \mathrm{~cm}$, the seat height should be $40.95 \mathrm{~cm}$ as shown in table 3 .

- Seat width: The hip breadth should be considered in the design of the seat width. Musa \& Ismaila, (2014), recommended $95^{\text {th }}$ percentile of hip breadth and allowance of 15 percent for clothing. In this study, the $95^{\text {th }}$ percentile of the hip breadth of $39.36 \mathrm{~cm}$ is used with an allowance of 15 percent of value $(5.9 \mathrm{~cm})$ which translates to a seat width of $45.26 \mathrm{~cm}$ as shown in table 3.

- Seat depth: The anthropometric dimension to be considered in the design of the seat depth is the buttock popliteal length. Mohamed et al., (2010), suggested $5^{\text {th }}$ percentile of the buttock popliteal length should be used to determine the seat depth. In this study, the $5^{\text {th }}$ percentile of the buttock popliteal length and hence the seat depth is $38.10 \mathrm{~cm}$ as shown in table 3. 
- $\quad$ Backrest height (Upper): For the design of the upper part of the backrest, the shoulder height (sitting) is considered. The $5^{\text {th }}$ percentile of sitting shoulder height used by Mohamed et al., (2010), is adopted in the current study and this dimension is $50.96 \mathrm{~cm}$ from the seat surface as shown in table 3 .

- Desktop width: The literature review recommended by Ismaila et al., 2013b), the desktop width should be $24.20 \mathrm{~cm}$.

- Desktop length: According to Mohamed et al., (2010); and Ismaila et al., 2013b), the $50^{\text {th }}$ percentile of the forearm fingertip length is considered for the dimension of the desktop length are $47.44 \mathrm{~cm}$ table 3 shows.

By analysing all the anthropometric measurements of the students, the desktop-chair is proposed, which can cover the maximum number of students at the selected institutions.

Table 3. Recommended dimensions for a new desktop-chair for use in the four selected tertiary institutions.

\begin{tabular}{|l|l|l|l|}
\hline Seat feature & $\begin{array}{l}\text { Anthropometric } \\
\text { measure }\end{array}$ & $\begin{array}{l}\text { Design } \\
\text { dimensions }(\mathrm{cm})\end{array}$ & Criteria/Determinant \\
\hline Seat height & Popliteal height & 40.95 & $\begin{array}{l}5^{\text {th }} \text { percentile of popliteal height }+0.45 \mathrm{~cm} \\
\text { shoe heel allowance }\end{array}$ \\
\hline Seat width & Hip breadth & 45.26 & $\begin{array}{l}95^{\text {th }} \text { percentile of hip breadth }+15 \% \\
\text { allowance for clothing }\end{array}$ \\
\hline Seat depth & $\begin{array}{l}\text { Buttock popliteal } \\
\text { length }\end{array}$ & 38.10 & $5^{\text {th percentile of buttock popliteal length }}$ \\
\hline $\begin{array}{l}\text { Desktop height } \\
\text { from seat }\end{array}$ & Elbow height & 19.11 & $5^{\text {th }}$ percentile of elbow-height \\
\hline Backrest height & Shoulder height & 50.96 & $5^{\text {th }}$ percentile of shoulder-height \\
\hline Desktop width & - & 24.20 & Literature review suggestions \\
\hline $\begin{array}{l}\text { Desktop length } \\
\text { Forearm fingertip }\end{array}$ & 47.44 & $50^{\text {th }}$ percentile of forearm fingertip length \\
\hline Backrest angle & - & $109^{0}$ & Literature review suggestions \\
\hline Seat angle & - & $110^{0}$ & From literature review \\
\hline
\end{tabular}

As shown in table 3, the seat height of proposed concept desktop-chair should be $40.59 \mathrm{~cm}$ for the students in the four selected tertiary institutions. Otherwise, table 5 shows the seat heights of existing chairs in these tertiary institutions are $48.10 \mathrm{~cm}$ (desktop-chair), $46.00 \mathrm{~cm}$ (steel foldable chair), $48.26 \mathrm{~cm}$ (wood foldable chair), and 42.50 (fixed chair) and that make the seats to be high for the students. Therefore, high a seat makes the underside of the thigh to become compressed causing discomfort and restriction in blood circulation (Ismaila et al., 2013a). The proposed dimension of the seat height in this research is lower than $52 \mathrm{~cm}$ recommended by Al-Hinai et al., (2018a) for students in Sultan Qaboos University in Finland, $44.50 \mathrm{~cm}$ proposed by Mohamed et al., (2010) for students in Sri Lanka, and also higher than $38.60 \mathrm{~cm}$ proposed by Tunay \& Melemez, (2008) for Turkish students, $37.70 \mathrm{~cm}$ proposed by Mououdi, (1997) for students in higher institutions in Iran and $36.45 \mathrm{~cm}$ proposed by Ismaila et al., (2013a) for students in tertiary institutions in Nigeria as shown in table 4. Thus, this predisposes that chairs designed for the students in these countries, especially Finland and Nigeria may not be comfortable for Kenyan students. Furthermore, from the present research, the seat depth should be $38.10 \mathrm{~cm}$ for the students in the four selected tertiary institutions. However, table 5 shows the seat depths of the existing chairs are $35.51 \mathrm{~cm}$ (desktopchair), $41.91 \mathrm{~cm}$ (steel foldable chair), $20.32 \mathrm{~cm}$ (wood foldable chair) and 48.26 (fixed chair), which makes the seat deep for the students shallow and large. However, large a depth does not allow an appropriate use of back support, which causes curvature of the spine (kyphosis) and may lead to an uncomfortable posture. And the shallow a seat may cause the user to have the sensation of falling off and may result in back of support of the lower thighs (Ismaila et al., 2013b). In these selected institutions, therefore, there is a mismatch between the students' body dimensions and the classroom furniture dimensions that may have discomfort for students in the long run.

Table 4. Comparison of dimensions of the seat height of new desktop-chair with selected countries.

\begin{tabular}{|l|l|l|l|}
\hline $\begin{array}{l}\text { Dimensions and country / } \\
\text { Institutions }\end{array}$ & Country & $\begin{array}{l}\text { Seat height } \\
(\mathrm{cm})\end{array}$ & References \\
\hline for students in Sultan Qaboos University in Finland & Finland & 52.00 & (Al-Hinai et al., 2018) \\
\hline For students in height institutions in Sri Lank & Sri Lanka & 44.50 & (Mohamed et al., 2010) \\
\hline For students in tertiary institutions in Kenya & Kenya & 40.59 & \\
\hline for Turkish students & Turkish & 38.60 & $\begin{array}{l}\text { (Tunay \& Melemez, } \\
\text { 2008) }\end{array}$ \\
\hline for students in higher institutions in Iran & Iran & 37.70 & (Mououdi, 1997) \\
\hline For students in tertiary institutions in Nigeria & Nigeria & 36.45 & (Ismaila et al., 2013) \\
\hline
\end{tabular}




\subsection{Characteristics of the Chairs in the Four Selected Tertiary Institutions}

Many types of classroom chairs were identified in the four selected tertiary institutions in Uasin-Gishu County, Kenya. The dimensions were different in the respective institutions, due to different companies may have constructed them (Ismaila et al., 2013b), as shown in table 5.

Table 5. Dimensions of the existing classroom furniture in the four selected tertiary institutions.

\begin{tabular}{|l|l|l|}
\hline Types of the existing classroom furniture & Seat height $(\mathrm{cm})$ & Seat depth $(\mathrm{cm})$ \\
\hline Desktop-chair & 48.10 & 35.51 \\
\hline Steel foldable chair & 46.00 & 41.91 \\
\hline Wood foldable chair & 48.26 & 20.32 \\
\hline Fixed chair & 42.50 & 48.26 \\
\hline
\end{tabular}

After, running the analysis of the recorded data, as shown in table 4.12, there is one type of innovative ergonomically suitable desktop-chair design was identified in the four selected tertiary institutions. The proposed innovative ergonomic desktop-chair design was drawn using SolidWorks 2019, software, as shown in figures 2a and $2 b$.

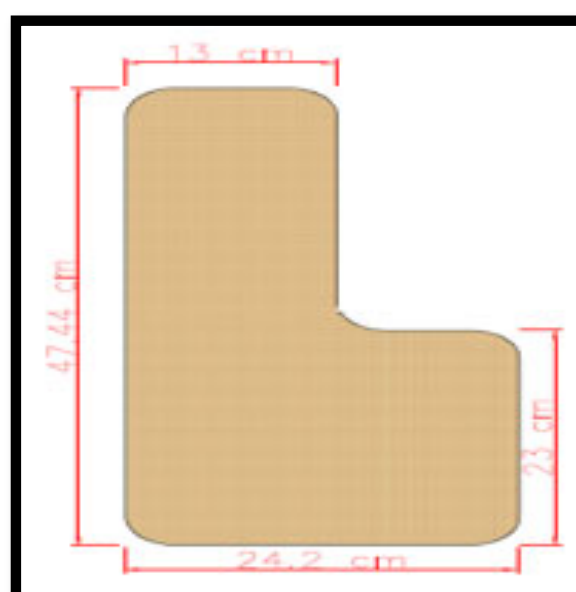

1

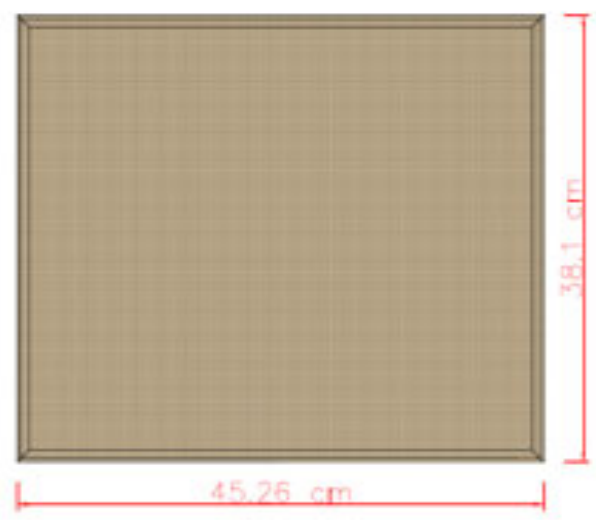

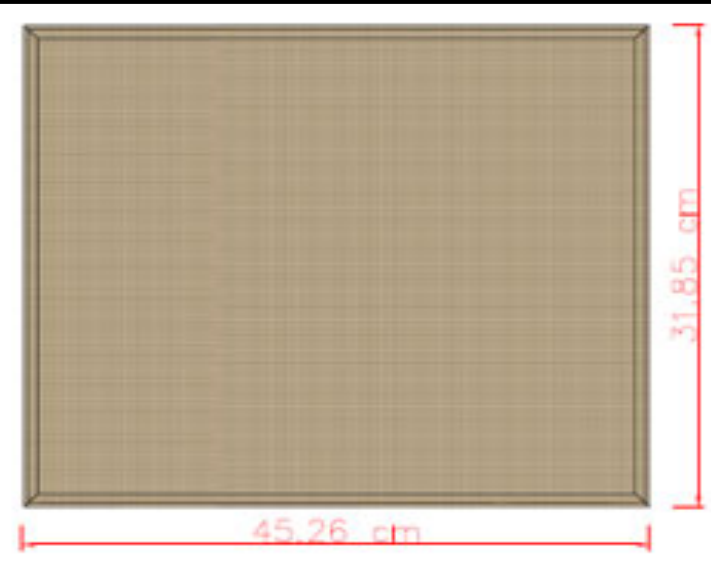

2

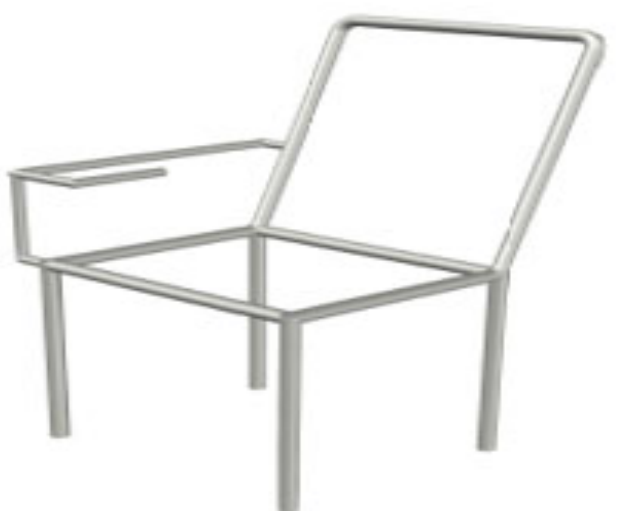

2

Keys:

1 Desktop

2 Backrest

3 Seat

4 Frame

Figure 2a. Sketches of the proposed students' desktop-chair. 


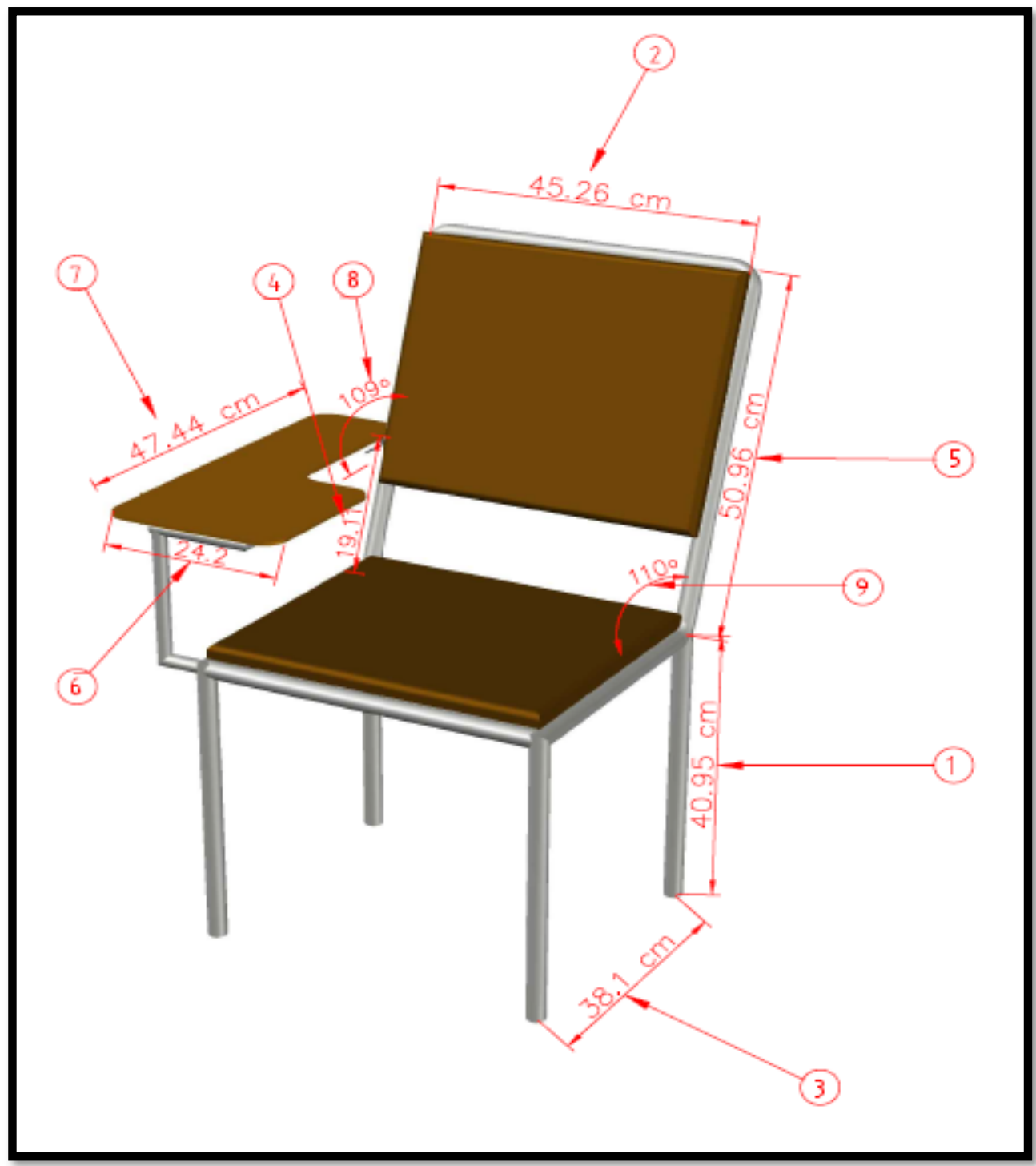

Keys:

\begin{tabular}{ll}
\hline 1 & Seat height \\
2 & Seat width \\
3 & Seat depth \\
4 & Desktop height from seat \\
5 & Backrest height \\
6 & Desktop width \\
7 & Desktop length \\
8 & Backrest angle \\
9 & Seat angle \\
\hline
\end{tabular}

Figure 2b. Complete model of the proposed students' desktop-chair

\section{Conclusions and Recommendations}

The main contribution of this research is providing a new database of anthropometric measurements for students at four selected tertiary institutions, Uasin-Gishu County, Kenya. The results revealed that mismatch between the students' body dimensions and the classroom desktop-chairs dimensions that may have discomfort for students in the long run. From the present research, it is well expected that criteria determinant for an adjustable desktop-chair needs to be used whenever designers wish to have adjustable classroom furniture (which is ergonomic design desktop-chairs) in the four selected tertiary institutions, Uasin-Gishu County, Kenya. In this research, therefore, there is one type of innovative ergonomically suitable classroom desktop-chair design was proposed to improve the match between classroom desktop-chairs dimensions and students' anthropometric characteristics. To ascertain a potential, though, the authors proposes further research on prototyping, usability and durability testing to be 
carried out in order to observe the interaction between the user and the product and evaluate its effectiveness and find possible problems of it.

Finally, analogous to Starovoytova, (2018), it is emphasized that there is absolutely nothing that can ever be perfect made by man, especially when it is at its initial stages and therefore, constructive expert criticism and relevant comments are welcomed from the readers for further improvement. The goal is not to be perfect, it is just to be better than before (Pusca \& Northwood, 2018).

\section{Acknowledgements}

The authors wish to acknowledge all heads of the institutions for their approvals to carry out the research and to all students who were involved in the anthropometric measurement as well as Monica Achieng for assistance provided in measurements of female subjects of the study. Sincere gratitude further goes to the ACEII-PTRE for fully funding this research.

\section{References}

Al-Hinai, N., Al-Kindi, M., \& Shamsuzzoha, A. (2018). An Ergonomic Student Chair Design and Engineering for Classroom Environment. International Journal of Mechanical Engineering and Robotics Research, 7(5), 534-543. https://doi.org/10.18178/ijmerr.7.5.534-543

Ansari, S., Nikpay, A., \& Varmazyar, S. (2018). Design and Development of an Ergonomic Chair for Students in Educational Settings. Health Scope, In Press(In Press). https://doi.org/10.5812/jhealthscope.60531

Biswas, B., Bintay Zahid, F., Ara, R., Parvez, M., \& Hoque, A. (2014). Mismatch Between Classroom Furniture and Anthropometric Measurements of Bangladeshi Primary School Students. International Conference on Mechanical, Industrial and Energy Engineering.

Esmaeel, A., \& Order, S. (2017). International Standard Technological Design —, 2017.

Igbokwe, O., Osueke, O., Opara, V, Ileagu, O., \& Ezeakaibeya, U. (2019). Considerations of Anthropometrics in the Design of Lecture Hall Furniture, 7(August), 374-386. https://doi.org/10.5281/zenodo.3401350

Ismaila, S., Musa, I., Adejuyigbe, S., \& Akinyemi, O. (2013a). Anthropometric Design of Furniture for Use in Tertiary Institutions in Abeokuta, South-Western Nigeria. Engineering Review, 33(3), 179-192.

Ismaila, O., Musa, I., Adejuyigbe, B., \& Akinyemi, D. (2013b). Anthropometric design of Furniture for Use In Tertiary Institutions in Abeokuta, South-Western Nigeria. Engineering Review, 33(3), 179-192.

Leilanie Del Prado-Lu, J. (2004). Risk Factors to Musculoskeletal Disorders and Anthropometric Measurements of Filipino Manufacturing Workers. International Journal of Occupational Safety and Ergonomics, 10(4), 349-359. https://doi.org/10.1080/10803548.2004.11076618

Macedo, C., Morais, V., Martins, F., Martins, C., Pais, M., \& Mayan, S. (2015). Match Between Classroom Dimensions and Students' Anthropometry: Re-equipment according to european educational furniture standard. Human Factors, 57(1), 48-60. https://doi.org/10.1177/0018720814533991

Mohamed Thariq, G., Munasinghe, P., \& Abeysekara, D. (2010). Designing Chairs With Mounted Desktop for University Students: Ergonomics and Comfort. International Journal of Industrial Ergonomics, 40(1), 818. https://doi.org/10.1016/j.ergon.2009.10.003

Mououdi, A. (1997). Static Anthropometric Characteristics of Tehran University Students Age 20-30. Applied Ergonomics, 28(2), 149-150. https://doi.org/10.1016/S0003-6870(95)00060-7

Musa, I., \& Ismaila, O. (2014). Student Anthropometric Data and Furniture Mismatches in Selected Institutions in Abeokuta, Ogun State, Nigeria. Theoretical Issues in Ergonomics Science, 15(2), $205-213$. https://doi.org/10.1080/1463922X.2011.611272

Pusca, D., \& Northwood, O. (2018). Design Thinking and Its Application to Problem Solving, (March).

Scott Openshaw, A., \& Erin Taylor, A. (2006). Ergonomics and Design A Reference Guide. Allsteel, 1-2. https://doi.org/10.1016/j.aninu.2017.06.001

Sepehri, S., Habibi, H., \& Shakerian, S. (2013). The Relationship Between Ergonomic Chair And Musculoskeletal Disorders in North of Khuzestan's students. European Journal of Experimental Biology, Available Online at Www.Pelagiaresearchlibrary.Com ISSN: 2248 -9215, 3(4), 181-187.

Starovoytova, D. (2018). Snoring and Its Management ( Part 2 / 2 ): Preliminary Design and Prototyping of AntiSnoring Chin Strap Device Snoring and Its Management ( Part 2 / 2 ): Preliminary Design and Prototyping of Anti-Snoring Chin Strap Device, (May).

Taifa, W., \& Desai, A. (2017). Anthropometric Measurements for Ergonomic Design of Students' Furniture in India. Engineering Science and Technology, an International Journal, 20(1), 232-239. https://doi.org/10.1016/j.jestch.2016.08.004

Tunay, M., \& Melemez, K. (2008). An Analysis of Biomechanical and Anthropometric Parameters on Classroom Furniture Design. African Journal of Biotechnology, 7(8), 1081-1086. 